\title{
Structure of the xenotropic murine leukaemia virus-related virus matrix protein
}

\author{
Michal Doležal ${ }^{1,2}$, Iva Pichová1, Tomáš Ruml ${ }^{2}$, Richard Hrabal ${ }^{3}$, Michaela Rumlová $^{*}$ \\ From 15th International Conference on Human Retroviruses: HTLV and Related Viruses \\ Leuven and Gembloux, Belgium. 5-8 June 2011
}

We present the preparation of the xenotropic murine leukaemia virus-related virus matrix protein (XMRVMA) and its structure determined by NMR spectroscopy.

The DNA fragment encoding XMRV-MA was obtained from prostate tumour cell cDNA (Rv1 cell line) by PCR and inserted into a pET-22b plasmid. Non-myristoylated, uniformly $13 \mathrm{C}$ - and 15N-labeled XMRV-MA, fused with histidine tag, was produced in E. coli BL21 (DE3) cells. The protein was purified by immobilized metal affinity chromatography (NiNTA-agarose) and size-exclusion chromatography (Sephadex 75), and then concentrated to $5 \mathrm{mg} / \mathrm{ml}$.

All NMR data were collected at $298 \mathrm{~K}$ on a $600 \mathrm{MHz}$ Bruker Avance III spectrometer equipped with a cryogenic triple-resonance probe and analyzed with $\mathrm{CcpNmr}$ Analysis. Back-bone and side-chain resonances were assigned using standard NMR experiments and structural constraints were obtained from $13 \mathrm{C}$ - and $15 \mathrm{~N}$-edited NOESY experiments. Structures were calculated with ARIA.

Although the protein sequence of the XMRV-MA is very similar to that of the murine leukaemia virus matrix protein (MLV-MA), it varies in several amino acid residues. We compared the structures of the XMRV-MA and MLV-MA and found that those changes are localized in a few domains, mostly on the surface of the protein.

\section{Author details}

'Institute of Organic Chemistry and Biochemistry, IOCB Research Centre and Gilead Sciences, Academy of Sciences of the Czech Republic, Prague, 166 10, Czech Republic. ${ }^{2}$ Department of Biochemistry and Microbiology, Institute of Chemical Technology Prague, Prague, 166 28, Czech Republic. ${ }^{3}$ Laboratory of

\footnotetext{
* Correspondence: rumlova@uochb.cas.cz

'Institute of Organic Chemistry and Biochemistry, IOCB Research Centre and Gilead Sciences, Academy of Sciences of the Czech Republic, Prague, 166 10, Czech Republic

Full list of author information is available at the end of the article
}

NMR spectroscopy, Institute of Chemical Technology Prague, Prague, 16628 , Czech Republic.

Published: 6 June 2011

doi:10.1186/1742-4690-8-S1-A227

Cite this article as: Doležal et al:: Structure of the xenotropic murine leukaemia virus-related virus matrix protein. Retrovirology 2011 8(Suppl 1):A227.
Submit your next manuscript to BioMed Central and take full advantage of:

- Convenient online submission

- Thorough peer review

- No space constraints or color figure charges

- Immediate publication on acceptance

- Inclusion in PubMed, CAS, Scopus and Google Scholar

- Research which is freely available for redistribution

Submit your manuscript at www.biomedcentral.com/submit

\section{() Biomed Central}

C Biomed Central

C 2011 Doležal et al; licensee BioMed Central Ltd. This is an open access article distributed under the terms of the Creative Commons Attribution License (http://creativecommons.org/licenses/by/2.0), which permits unrestricted use, distribution, and reproduction in any medium, provided the original work is properly cited. 